\title{
KONSUMSI ZAT GIZI REMAJA PUTRI YANG MENGIKUTI EKSTRA KURIKULER MENARI DI KOTA DENPASAR
}

\author{
Ni Made Dewantari, I Komang Agusjaya Mataram, I Wayan Ambartana \\ Jurusan Gizi Poltekkes Denpasar \\ dewantarimade@yahoo.com
}

\begin{abstract}
Doing dance regularly and continuously turns a positive influence on body composition. Whether dance can be used as an alternative to achieve normal nutritional status? The aim of this study was to analyze differences in nutrient consumption of young women based extracurricular. Research conducted at SMUN Denpasar with research subjects who are still active teenage girls school at SMUN Denpasar, aged 15-18 years and followed extracurricular dance and journalism. The subjects included 131 people composed of 69 people danced and 62 journalism. The data collected is food consumption data with the recall method is then processed by a computer program then compared with adequacy. To analyze differences in the level of nutrient consumption among the dance with journalism used independent t-test or independent samples Mann Whitney test. The average consumption level of energy and carbohydrates are relatively more dancing than journalism, average consumption of protein and fat levels are relatively similar. There are differences energy consumption and carbohydrate consumption among young women who follow extracurricular dance with journalism. There is no difference protein consumption and fat consumption among young women who follow extracurricular dance with journalism.
\end{abstract}

Keywords: nutrient consumption; extracurricular dance and journalism

Abstrak. Melakukan gerak tari secara teratur dan berkesinambungan ternyata
memberikan pengaruh positif terhadap komposisi tubuh. Apakah menari dapat
dimanfaatkan sebagai alternatif untuk mencapai status gizi normal. Tujuan dari
penelitian ini adalah untuk menganalisis perbedaan konsumsi zat gizi remaja putri
berdasarkan ekstrakurikuler. Penelitian dilaksanakan di SMUN Denpasar dengan
subyek penelitian remaja putri yang masih aktif sekolah di SMUN Denpasar, berumur
15-18 tahun dan mengikuti ekstrakurikuler menari dan jurnalistik. Subyek penelitian
berjumlah 131 orang terdiri dari 69 orang menari dan 62 jurnalistik. Data yang
dikumpulkan adalah data konsumsi makanan dengan metode recall kemudian diolah
dengan program komputer selanjutnya dibandingkan dengan kecukupan. Untuk
menganalisis perbedaan tingkat konsumsi zat gizi antara yang menari dengan
jurnalistik digunakan uji independent t-test atau uji independen sampel Mann
Withney test. Rerata tingkat konsumsi energi dan karbohidrat yang menari relatif
lebih banyak daripada jurnalistik, rerata tingkat konsumsi protein dan lemak relatif
sama. Ada perbedaan tingkat konsumsi energi dan karbohidrat antara remaja putri
yang mengikuti ekstrakurikuler menari dengan jurnalistik. Tidak ada perbedaan
tingkat konsumsi protein dan lemak antara remaja putri yang mengikuti
ekstrakurikuler
Kata Kunari dengan Kata Kunci: konsumsi zat gizi; ekstrakurikuler menari dan jurnalistik 


\section{Pendahuluan}

Masa remaja merupakan masa transisi yang unik dan ditandai oleh berbagai perubahan fisik, emosi dan psikis. ${ }^{1} \quad$ Berdasarkan perubahanperubahan tersebut, kebutuhan energi dan zat gizi di usia remaja ditujukan untuk deposisi jaringan tubuhnya. Apalagi di masa ini, aktivitas fisik remaja pada umumnya lebih banyak. Selain disibukan dengan aktivitas belajar di sekolah, umumnya mereka juga menekuni berbagai kegiatan ekstrakurikuler seperti menari. Semua itu tentu akan menguras energi, yang berujung pada keharusan menyesuaikannya dengan asupan zat gizi yang seimbang. ${ }^{2}$ Namun pada usia remaja terdapat beberapa masalah yang berkaitan dengan asupan zat gizi seperti pola makan salah, maupun terganggunya kebiasaan makan. ${ }^{3}$ Mereka sulit makan teratur di rumah, ada kecendrungan untuk makan semaunya disertai dengan kesukaan makan junk foods seperti burger, pizza, dan fried chicken serta tidak sesuai jadwal makan.

Pada usia remaja juga merupakan masa seseorang mencari identitas diri, sehingga anak sangat peduli pada penampilan dan kondisi tubuh. Tak heran sebagian remaja, khususnya perempuan justru sering mengurangi makan karena takut gemuk. Hal ini lebih dikarenakan persepsi mereka tentang penampilan fisik (body image) yang keliru. Hasil penelitian Kusumajaya,dkk (2008) menunjukkan bahwa persepsi remaja terhadap body image $23,8 \%$ memiliki persepsi negatif atau menganggap diri mereka lebih gemuk. ${ }^{4}$ Akibatnya, remaja pun berusaha mengurangi makan sehingga terjadilah pola makan yang salah, yakni yang tidak ber-gizi seimbang. Semua ini tentunya akan berdampak terhadap status gizi remaja. Berdasarkan paparan di atas maka dilakukan penelitian yang bertujuan untuk mengetahui perbedaan konsumsi zat gizi antara remaja putri yang mengikuti ekstrakurikuler menari dengan tidak menari dalam hal ini adalah jurnalistik.

\section{Metode}

Penelitian ini merupakan penelitian observasional, dengan rancangan cross sectional. $^{5}$ Subyek penelitian adalah remaja putri dari empat SMUN di Kota Denpasar yaitu SMUN 2, SMUN 3, SMUN 5 dan SMUN 8 yang mengikuti ekstrakurikuler menari dan jurnalistik. 
Besar sampel pada masing-masing kelompok adalah 69 orang dan 62 orang.

Data yang dikumpulkan adalah data antropometeri (data berat badan, tinggi badan) dan data konsumsi makanan. Data konsumsi makanan dikumpulkan dengan metode recall $2 \mathrm{X}$ 24 jam. $^{6}$

Data yang telah terkumpul dikonversikan menggunakan program komputer untuk mengetahui jumlah asupan zat gizi yaitu energi, protein, lemak dan karbohidrat yang dikonsumsi remaja per harinya. Selanjutnya dihitung tingkat konsumsi zat gizi dengan cara membandingkan jumlah asupan zat gizi per harinya dengan kebutuhan. Untuk menganalisis perbedaan konsumsi zat gizi antara remaja putri yang mengikuti ekstrakurikuler menari dengan jurnalistik digunakan uji independent t-test jika distribusi data normal. Jika distribusi data tidak normal dipakai uji non parametrik, yaitu independent sampel Mann-Whitney Test.

\section{Hasil dan Pembahasan}

Kebutuhan energi pada saat beraktivitas dapat dipenuhi melalui sumber-sumber energi yang tersimpan di dalam tubuh yaitu melalui pembakaran karbohidrat, lemak serta pemecahan protein. Rerata tingkat konsumsi energi remaja putri yang mengikuti ekstra kurikuler menari lebih banyak (100,04 \pm $7,77 \%$ dari kebutuhan) dibandingkan dengan yang mengikuti jurnalistik $(94,05 \pm 12,25 \%$ dari kebutuhan) dan keduanya sudah tergolong cukup sesuai yang dianjurkan yaitu sekitar 90-110\% dari kebutuhan untuk dapat melakukan aktivitas menari maupun jurnalistik. Hasil uji statistik didapatkan nilai $\mathrm{p}=0,001$ pada $\alpha=0,05$ berarti ada perbedaan yang signifikan rerata tingkat konsumsi energi antara remaja putri yang mengikuti ekstrakurikuler menari dengan jurnalistik.

Hasil penelitian ini berbeda dengan hasil penelitian Keska,A. (2013) terhadap 264 mahasiswa di Polandia yang dikategorikan aktif dan non aktif yang menyatakan tidak ada perbedaan yang signifikan dalam konsumsi energi antara mahasiswa yang aktif dan non-aktif. ${ }^{7}$ Sebaran tingkat konsumsi energi seperti pada tabel 1. 

Tabel 1.

Sebaran Tingkat Konsumsi Energi Remaja Putri Menurut Ekstrakurikuler

\begin{tabular}{ccccc}
\hline Tingkat Konsumsi & \multicolumn{2}{c}{ Menari } & \multicolumn{2}{c}{ Jurnalistik } \\
\cline { 2 - 5 } Energi & $\mathrm{f}$ & $\%$ & $\mathrm{f}$ & $\%$ \\
\hline Lebih & 4 & 5.8 & 10 & 16.1 \\
Cukup & 58 & 84,1 & 23 & 37,1 \\
Kurang & 7 & 10,1 & 29 & 48,8 \\
\hline Jumlah & 69 & 100.0 & 62 & 100.0 \\
\hline
\end{tabular}

Sebaran tingkat konsumsi energi dengan kategori cukup, lebih banyak pada remaja yang mengikuti ekstrakurikuler menari $(84,1 \%)$ dibandingkan jurnalistik $(37,1 \%)$. Sebaliknya kategori kurang, lebih banyak jurnalistik $(48,8 \%)$ dibandingkan menari $(10,1 \%)$. Remaja putri yang mengikuti ekstrakurikuler menari mengeluarkan energi lebih banyak karena aktivitas fisiknya lebih tinggi dibandingkan dengan yang mengikuti ekstrakurikuler jurnalistik.

Peningkatan aktivitas fisik yang dilakukan seseorang diiringi dengan peningkatan pemakaian energi. Kebutuhan energi yang tinggi selama periode remaja, sedangkan yang dipergunakan untuk deposisi jaringan dan pertumbuhan hanya $3 \%$ dari total energi yang dibutuhkan. Jadi, kebutuhan energi yang tinggi tersebut sebagian besar diperlukan untuk maintenen dan aktifitas fisik dibandingkan untuk pertumbuhan. ${ }^{8}$

Menurut Sharkey (2011) menyatakan bahwa menari modern sedang hingga berat, mengeluarkan energi 4,2-5,7 Kalori per menit. ${ }^{9}$ Hal senada diungkapkan oleh Triangto (2005) bahwa aktivitas berdansa cepat yang dilakukan selama 30 menit dapat membakar 150 Kalori setara dengan senam aerobik intensitas sedang, berjalan kaki maupun bersepeda. ${ }^{10}$ Sedangkan aktivitas duduk sambil menulis yang banyak dilakukan oleh remaja yang mengikuti ekstrakurikuler jurnalistik mengeluarkan energi 2,6 kalori per menit.

Protein merupakan salah satu jenis zat gizi yang mempunyai fungsi penting sebagai bahan dasar untuk pembentukan jaringan tubuh dan memperbaiki jaringanjaringan tubuh yang telah rusak. ${ }^{11}$ Rerata tingkat konsumsi protein remaja putri yang mengikuti ekstrakurikuler menari 
dan jurnalistik relatif sama yaitu masingmasing $95,59 \pm 8,75 \%$ dan $95,24 \pm 9,06$ dari kebutuhan dan ini sudah tergolong cukup. Hasil uji statistik didapatkan nilai $\mathrm{p}=$ 0,906 pada $\alpha=0,05$ berarti tidak ada perbedaan yang signifikan rerata tingkat konsumsi protein antara remaja putri yang mengikuti ekstrakurikuler menari dengan jurnalistik. Sebaran tingkat konsumsi protein seperti pada Gambar 1.

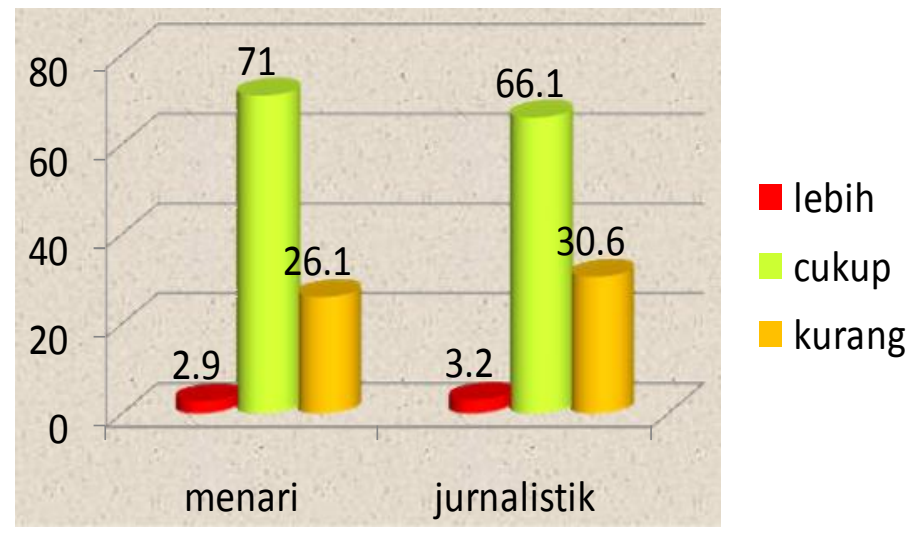

Gambar 1. Sebaran Tingkat Konsumsi Protein Menurut Ekstrakurikuler

Sebaran tingkat konsumsi protein remaja putri yang mengikuti ekstra kurikuler menari maupun jurnalistik, sebagian besar termasuk kategori cukup dengan persentase masing-masing yaitu $71,0 \%$ dan $66,1 \%$. Namun masih ada dengan kategori kurang 26,1\% pada yang menari dan 30,6\% pada jurnalistik. Penggunaan protein sebagai sumber energi baru akan terpakai jika simpanan karbohidrat ataupun lemak tidak lagi mampu untuk menghasilkan energi yang dibutuhkan oleh tubuh.

Penggunaan protein sebagai sumber energi akan mengurangi fungsi utamanya sebagai bahan pembangun tubuh serta fungsinya untuk memperbaiki jaringan tubuh yang telah rusak. ${ }^{12}$

Lemak menduduki tempat kedua sebagai sumber energi setelah karbohidrat. Rerata tingkat konsumsi lemak remaja yang mengikuti ekstra menari dan jurnalistik relatif sama yaitu masingmasing adalah 97,61 $\pm 8,94 \%$ dan 95,95 $\pm 11,53$. Hasil uji statistik didapatkan nilai $\mathrm{p}=0,519$ pada $\alpha=0,05$ berarti tidak ada perbedaan yang signifikan rerata tingkat konsumsi protein antara remaja putri yang mengikuti ekstrakurikuler menari dengan jurnalistik. 
Sebaran tingkat konsumsi lemak seperti pada Gambar 2.

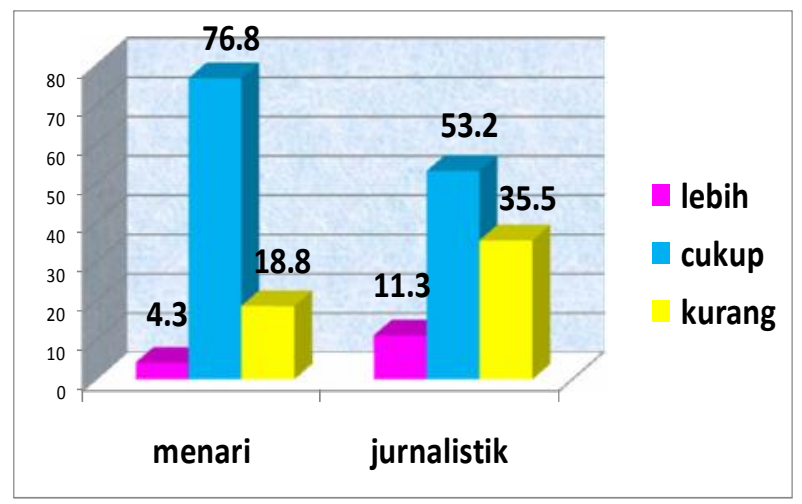

Gambar 2. Sebaran Tingkat Konsumsi Protein Menurut Ekstrakurikler

Sebaran tingkat konsumsi lemak dengan kategori cukup lebih banyak pada yang menari $(76,8 \%)$ dibandingkan jurnalistik $(53,2 \%)$. Sedangkan kategori kurang, lebih banyak dijumpai pada remaja yang mengikuti ekstrakurikuler jurnalistik $(35,5 \%)$ dibandingkan menari $(18,8 \%)$. Lemak memegang peranan penting sebagai sumber asam lemak esensial yang diperlukan untuk pertumbuhan, sebagai sumber energi yang berkadar tinggi, dan sebagai pengangkut vitamin yang larut dalam lemak. Sebagian kecil remaja putri yang mengikuti ekstrakurikuler menari maupun jurnalistik mengkonsumsi lemak dengan kategori lebih. Konsumsi lemak melebihi kebutuhan, dapat terjadi karena jenis makanan yang dikonsumsi remaja dominan makanan yang diolah dengan cara digoreng dan fast food seperti fried chicken, siomay, Pizza. Pada aktivitas dengan intensitas rendah dengan waktu durasi yang panjang, pembakaran lemak akan memberikan kontribusi yang lebih besar dibandingkan dengan pembakaran karbohidrat dalam hal produksi energi tubuh.

Karbohidrat merupakan zat gizi sumber energi yang tidak hanya berfungsi untuk mendukung aktivitas fisik namun karbohidrat juga merupakan sumber energi utama bagi sistem saraf pusat termasuk otak. Rerata tingkat konsumsi karbohidrat remaja yang mengikuti ekstrakurikuler menari $(103,19 \pm 9,41)$ lebih banyak dibandingkan dengan jurnalistik $(93,91 \pm 14,33 \%)$. Hasil uji 
statistik diperoleh nilai $\mathrm{p}=0,001$ pada $\alpha$ $=0,05$ berarti ada perbedaan yang signifikan rerata tingkat konsumsi karbohidrat antara remaja putri yang mengikuti ekstrakurikuler menari dengan jurnalistik. Sebaran tingkat konsumsi karbohidrat seperti pada Gambar 3.

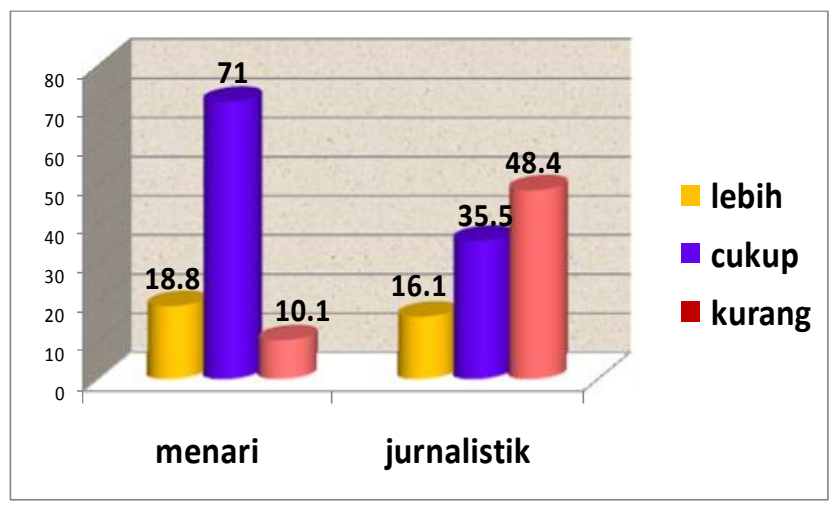

Gambar 3. Sebaran Tingkat Konsumsi Karbohidrat Menurut Ekstrakurikuler

Sebaran tingkat konsumsi karbohidrat dengan kategori kurang, lebih banyak pada yang mengikuti ekstra kurikuler jurnalistik $(48,4 \%)$ dibandingkan dengan menari $(10,1 \%)$. Sebaliknya kategori cukup, lebih banyak pada yang menari $(71,1 \%)$ dibandingkan jurnalistik $(35,5 \%)$. Aktivitas fisik remaja putri yang mengikuti ekstrakurikuler menari lebih tinggi dibandingkan dengan yang mengikuti ekstra kurikuler jurnalistik sehingga membutuhkan energi yang lebih tinggi. Sumber terbesar energi tubuh adalah karbohidrat. Penggunaan karbohidrat oleh tubuh sebagai sumber energi untuk dapat mendukung kerja otot pada saat olahraga termasuk juga menari terutama apabila aktivitas menari dilakukan dengan intensitas moderattinggi dengan waktu durasi yang tidak terlalu lama maka karbohidrat akan berfungsi sebagai sumber energi utama tubuh dan akan memberikan kontribusi yang lebih besar dibandingkan dengan lemak dalam memproduksi energi di dalam tubuh. ${ }^{12}$

\section{Simpulan}

Ada perbedaan tingkat konsumsi energi dan karbohidrat antara remaja putri yang mengikuti ekstrakurikuler menari dengan jurnalistik. Namun tidak ada 
perbedaan tingkat konsumsi protein dan lemak antara remaja putri yang mengikuti ekstrakurikuler menari dengan jurnalistik.

\section{Daftar Pustaka}

1. Soetjiningsih,2007, Tumbuh Kembang Remaja dan Permasalahannya, Jakarta: CV, Sagung Seto.

2. Arisman. 2010. Gizi dalam Daur Kehidupan. Jakarta; Penerbit Buku Kedokteran EGC.

3. Insel,P. R.E. Turner and D.Ross. 2002. Nutrition. Canada: Jones and Bartlett Publisher,Inc.

4. Kusumajaya, Wiardani dan Juni Arsana. 2008. Persepsi Remaja Terhadaop Body Image (Citra Tubuh) Kaitannya dengan Pola Konsumsi Makan dan Status Gizi dalam Jurnal Skala Husada Vol. 5 No. 2 Hal.114125.

5. Sastroasmoro,S. dan Sofyan Ismail. 2008. Dasar-dasar Metodelogi Penelitian Klinis. Jakarta: Sagung Seto.

6. Supariasa, IDN., Bachyar Bakri dan Ibnu Fajar, 2012, Penilaian Status Gizi, Jakarta : EGC.

7. Keska,A., Malgozata Sobczak, Grazyna Lutoslawska, Krzysztof Mazurek, Joanna Traczyk, Anna Klos and Jerzy Bertrandt. 2013. Indices of Body Composition, Energy and Macronutrient Intakes in Young Men and Women With Different Physical Activity. Journal of Pre-clinical and Clinical Research, 2013, Vol.7, No.7: 36-39.

8. Almatsier, Sunita. 2004. Prinsip Dasar Ilmu Gizi. Jakarta : Gramedia Pustaka Utama.

9. Sharkey,B.J. 2011. Kebugaran \& Kesehatan. Jakarta: PT Rajagrafindo Persada.
10. Tiangto,M. 2005. Jalan Sehat dengan Sports Therapy, Seri Inti sari Kesehatan. Jakarta: PT. Intisari Mediatama.

11. Adriani, M., Wirjatmadi, B., 2012. Pengantar Gizi Masyarakat. Cetakan ke-1, Jakarta: Kencana Prenada Media Grup

12. Irawan,M.Anwari. Nutrisi, Energi \& Performa Olahraga. Sports Science Brief, Vol 01, No.04. 2007 